\title{
Hexavalent Chromium Removal and Reduction to Cr (III) by Polystyrene Tris(2-aminoethyl)amine
}

\author{
Lina Odeh' ${ }^{1}$ Imad Odeh ${ }^{1 *}$, Mustafa Khamis' ${ }^{1}$ Mahmoud Khatib ${ }^{1}$, Mohannad Qurie ${ }^{2,3}$, \\ Ziad Shakhsher', Mutaz Qutob ${ }^{3}$ \\ ${ }^{1}$ Department of Chemistry and Chemical Technology, Al-Quds University, Jerusalem, Palestine \\ ${ }^{2}$ Center for Chemical and Biological Analysis, Al-Quds University, Jerusalem, Palestine \\ ${ }^{3}$ Department of Earth and Environmental Studies, Al-Quds University, Jerusalem, Palestine \\ Email: ${ }^{*}$ odehim@science.alquds.edu
}

Received 13 October 2014; revised 30 November 2014; accepted 17 December 2014

Copyright (C) 2015 by authors and Scientific Research Publishing Inc.

This work is licensed under the Creative Commons Attribution International License (CC BY).

http://creativecommons.org/licenses/by/4.0/

\section{(c) (i) Open Access}

\begin{abstract}
A commercially available chelating polymer, polystyrene tris(2-aminoethyl)amine, was used for the removal of chromium from aqueous solution. The influence of $\mathrm{pH}$, contact time, adsorbent dosage and initial $\mathrm{Cr}$ (VI) concentration on adsorption was studied. The optimum $\mathrm{pH}$ for the removal of $\mathrm{Cr}$ (VI) was at pH 5, while optimum contact time and adsorbent dosage were 120 minutes and $10 \mathrm{~g} / \mathrm{L}$, respectively. Total chromium and $\mathrm{Cr}$ (VI) concentrations were analyzed by ICP-MS and UVVisible. Adsorption isotherms using Langmuir and Freundlich isotherm models revealed that the data fitted Langmuir isotherm model better than Freundlich with a maximum adsorption capacity of $312.27 \mathrm{mg} / \mathrm{g}$. FTIR spectroscopy, Scanning electron microscopy (SEM) and Energy Dispersive Spectrometry (EDS) analyses were performed on the adsorbent before and after binding $\mathrm{Cr}$ (VI). All analyses confirmed the complexation of $\mathrm{Cr}$ (VI) to the adsorbent. Desorption experiments using $\mathrm{KCl}$ solution indicated $\mathbf{8 9 . 3 \%}$ release of chromium, rendering this method of high potential for adsorbent regeneration.
\end{abstract}

\section{Keywords}

Adsorption of Cr (VI), Polystyrene Tris(2-aminoethyl)amine, ICP-MS, SEM, EDS

\section{Introduction}

Chromium exists in the environment in two main oxidation states Cr (III) and Cr (VI) [1]. Cr (III) is an essential

"Corresponding author.

How to cite this paper: Odeh, L., Odeh, I., Khamis, M., Khatib, M., Qurie, M., Shakhsher, Z. and Qutob, M. (2015) Hexavalent Chromium Removal and Reduction to $\mathrm{Cr}$ (III) by Polystyrene Tris(2-aminoethyl)amine. American Journal of Analytical Chemistry, 6, 26-37. http://dx.doi.org/10.4236/ajac.2015.61003 
element for humans and is much less toxic than $\mathrm{Cr}(\mathrm{VI})$, it is required to potentiate insulin and for normal glucose metabolism [2] [3]. Cr (III) is poorly adsorbed by any route so the toxicity of chromium is attributed to the $\mathrm{Cr}$ (VI) form [4]. Cr (VI) can be absorbed by the lung and gastrointestinal tract, and even to a certain extent by intact skin. If $\mathrm{Cr}$ (VI) is reduced to $\mathrm{Cr}$ (III) extracellularly, the toxicity is not observed. Cr (VI) can be reduced intracellularly by hydrogen peroxide, glutathione reductase and ascorbic acid to produce reactive intermediates. Any of these species could attack DNA, proteins and membrane lipids thereby disrupting cellular integrity and functions. Exposure to chromium (VI) can cause respiratory, renal, hepatic, gastrointestinal, cardiovascular and hematological problems. Also $\mathrm{Cr}$ (VI) is considered to be carcinogenic [5] [6]. Cr (VI) is introduced into natural waters by a variety of industrial processes including textile, dyes and pigment production, film and photography, galvanometry, leather tanning, electroplating and metal finishing industries [7]. A number of treatment methods for the removal of metal ions from aqueous solutions have been reported. These include reduction, ion exchange, electro dialysis, electrochemical precipitation, evaporation, solvent extraction, reverse osmosis, chemical precipitation and adsorption. Most of these methods have a lot of disadvantages including high operational cost [8]. Recently, adsorption processes utilizing natural low cost adsorbents were employed in order to remove chromium from aqueous solutions. Some of these processes were also able to reduce $\mathrm{Cr}$ (VI) to $\mathrm{Cr}$ (III) [1] [10]-[13]. On the other hand, specific sorbents consisting of polymer microspheres containing metal chelating ligands were employed for heavy metal ion removal [9].

Herein, the use of polystyrene tris(2-aminoethyl)amine microspheres as an efficient matrix for the removal of $\mathrm{Cr}$ (VI) from aqueous solutions is reported. The effects of contact time, $\mathrm{pH}$ and adsorbent dosage on the adsorption efficiency are studied. The maximum adsorption capacity is evaluated using Langmuir adsorption isotherm and compared with reported values.

\section{Experimental}

\subsection{Chemicals and Materials}

Polystyrene tris(2-aminoethyl)amine, Potassium dichromate, 1,5-Diphenyl carbazide, sodium hydroxide, and sulfuric acid were purchased from Sigma-Aldrich (Israel) and were used as received. All solutions were prepared in deionized distilled water. Cr (VI) stock solution $(1000 \mathrm{mg} / \mathrm{L})$ was prepared by dissolving the appropriate amount of $\mathrm{K}_{2} \mathrm{Cr}_{2} \mathrm{O}_{7}$ in deionized distilled water. This solution was diluted as required to obtain $5.0-80 \mathrm{mg} / \mathrm{L}$ $\mathrm{Cr}$ (VI) standard solutions. The batch experiments were carried out in $100 \mathrm{ml}$ Erlenmeyer flasks by agitating a pre-weighed amount of the polymer with $50 \mathrm{ml}$ of the aqueous $\mathrm{Cr}(\mathrm{VI})$ solution at $25^{\circ} \mathrm{C} \pm 1^{\circ} \mathrm{C}$. The initial $\mathrm{pH}$ of the solution was adjusted using $0.2 \mathrm{~N} \mathrm{H}_{2} \mathrm{SO}_{4}$. A muli-element standard solution (51844) for calibration of the ICP-MS was obtained from Sigma-Aldrich (Israel).

\subsection{Analysis of Adsorbate and Adsorbent}

The concentration of Cr (VI) was determined colorimetrically using a Perkin-Elmer Lambda 5 UV-Visible spectrophotometer and the total Chromium concentration was determined using inductively coupled plasma-mass spectrometer (ICP-MS, Agilent Technologies 7500 Series). A calibration curve for Cr (VI) was obtained by plotting the absorbance of $\mathrm{Cr}$ (VI) solutions of different concentrations after complexation with the 1,5-diphenyl carbazide ligand at $540 \mathrm{~nm}$. The curve was linear within the selected Cr (VI) concentrations with a correlation coefficient $\left(\mathrm{R}^{2}\right)$ of 0.9996 . While a second calibration curve for total $\mathrm{Cr}$ was prepared by analyzing the standard solutions prepared from a multi-element standard solution by ICP-MS. The curve was linear through the selected concentrations with a correlation coefficient $\left(\mathrm{R}^{2}\right)$ of 0.9987 .

The adsorbent dosage was varied in the range of 2.00 and $30.0 \mathrm{~g} / \mathrm{L}$ with initial $\mathrm{Cr}$ (VI) concentration of 10.0 $\mathrm{mg} / \mathrm{L}$. Samples were analyzed for total $\mathrm{Cr}$ (ICP) and Cr (VI) (UV-Vis) concentrations after a contact time of 180 minutes and at $\mathrm{pH}=5.0$.

Scanning electron microscopy (SEM) and (EDS) analyses of the adsorbent before and after complexation with chromium ions were recorded on JEOL model, JSM-5410 LV-country. The samples were mounted on metal stubs and then coated with gold (Polaron Spatter coater). The images were taken with an accelerating voltage of $25 \mathrm{kV}$, at high vacuum (HV mode) and secondary electron image (SEI). The analysis was done using Oxford systems-Liquid Nitrogen cooled solid state Energy Dispersive Spectrometer detector and link ISIS software.

Regeneration of the polystyrene tris(2-aminoethyl)amine was performed by mixing the chromium-chelated 
adsorbent with $1 \mathrm{M} \mathrm{KCl}$ aqueous solution and then agitated for 2 hours. The regenerated adsorbent was tested by agitating it with $10 \mathrm{ppm} \mathrm{Cr}$ (VI) solution for 2 hours and the percent removal was calculated by determining the initial and the final concentration of $\mathrm{Cr}(\mathrm{VI})$ in the solution using the colorimetric method.

\section{Results and Discussion}

\subsection{Effect of Adsorbent Dosage}

Figure 1 and Figure 2 summarize the effect of adsorbent dosage on the percent removal of $\mathrm{Cr}$ (VI) and total Cr, respectively. Inspection of these figures reveals that the percent removal of $\mathrm{Cr}$ (VI) and of total $\mathrm{Cr}$ increased with increasing adsorbent dosage and attained a constant value after a dosage of $10 \mathrm{~g} / \mathrm{L}$. Hence the optimum dosage for the removal of $\mathrm{Cr}(\mathrm{VI})$ by polystyrene tris(2-aminoethyl)amine was set at $10.0 \mathrm{~g} / \mathrm{L}$.

\subsection{Effect of Contact Time}

The effect of contact time on the percent removal of $\mathrm{Cr}(\mathrm{VI})$ and on the concentration of total Cr by polystyrene tris-(2-aminoethyl)amine with the optimum dosage of $10 \mathrm{~g} / \mathrm{L}$ is demonstrated in Figure 3 and Figure 4. The

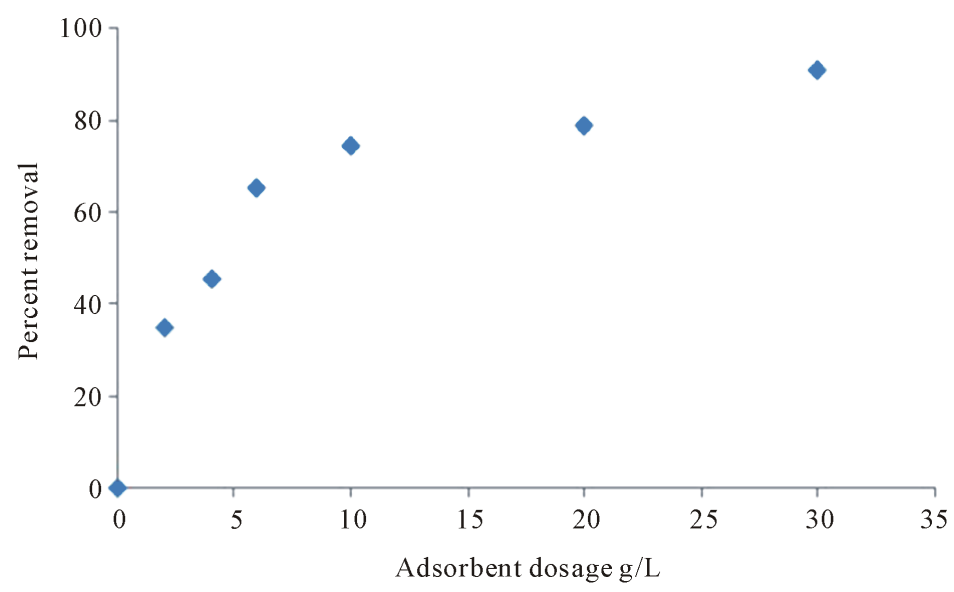

Figure 1. Percent removal of Cr (VI) on polystyrene tris(2-aminoethyl) amine as a function of adsorbent dosage as determined by UV-Visible spectroscopy $\left(T=25^{\circ} \mathrm{C}\right.$, Contact time $=3$ hours, $\mathrm{pH}=5$, Initial concentration $=10 \mathrm{ppm})$.

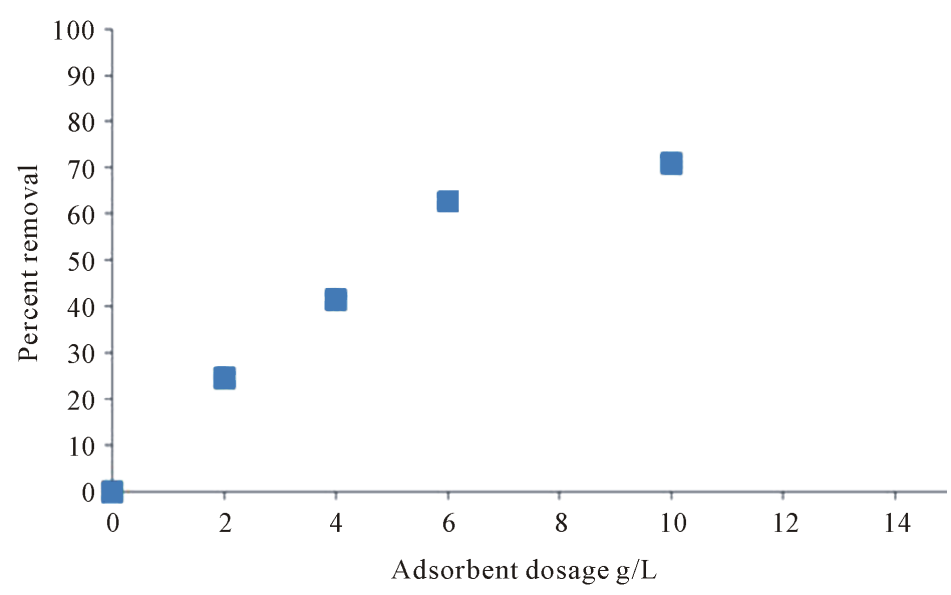

Figure 2. Percent removal of total $\mathrm{Cr}$ on polystyrene tris(2-aminoethyl) amine as a function of adsorbent dosage as determined by ICP-MS spectrometry $\left(T=25^{\circ} \mathrm{C}\right.$, Contact time $=3$ hours, $\mathrm{pH}=5$, Initial concentration $=10 \mathrm{ppm})$. 


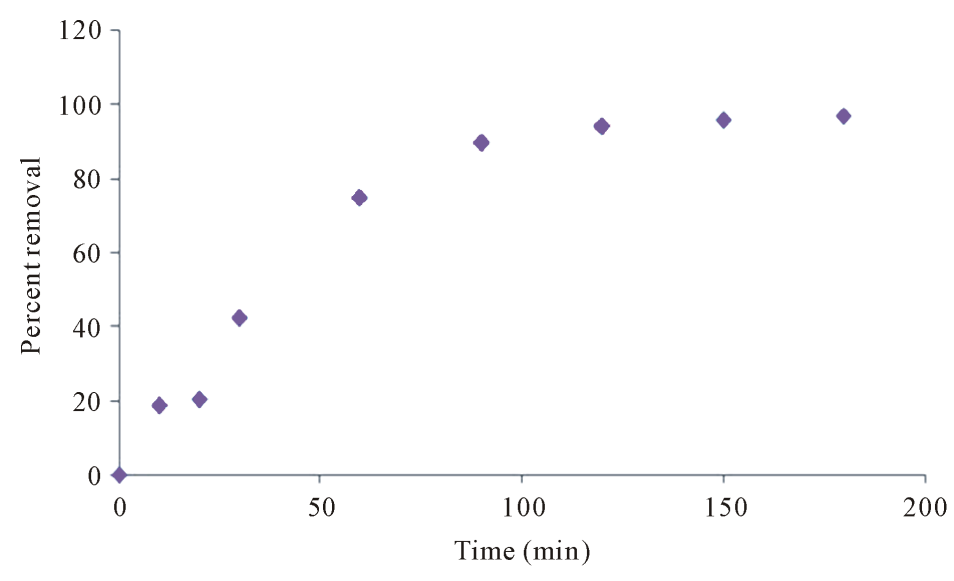

Figure 3. Percent removal of Cr (VI) on polystyrene tris(2-aminoethyl) amine as a function of contact time by UV-Visible spectroscopy ( $T=$ $25^{\circ} \mathrm{C}, \mathrm{pH}=5$, Adsorbent dosage $=10 \mathrm{~g} / \mathrm{L}$, Initial concentration of $\mathrm{Cr}(\mathrm{VI})$ $=10 \mathrm{ppm})$.

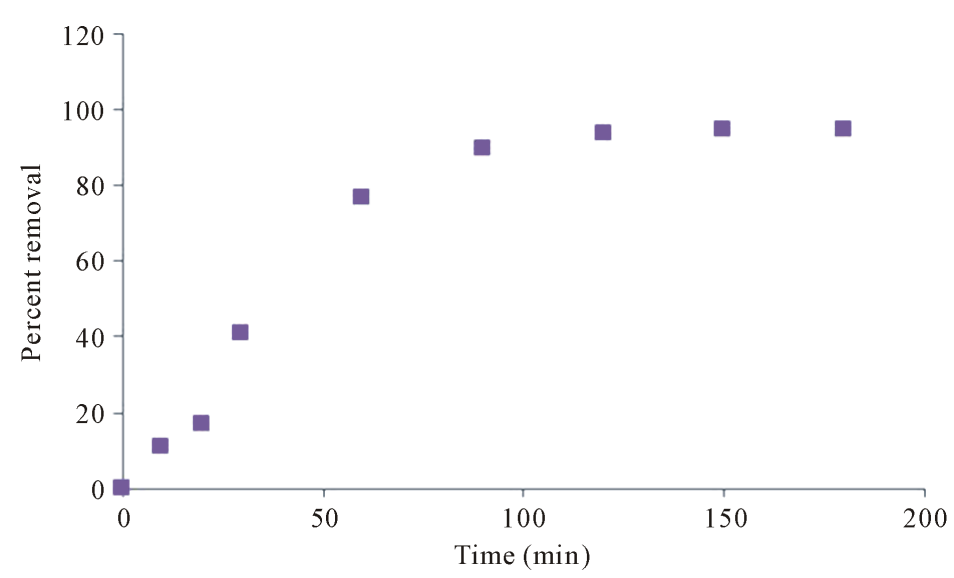

Figure 4. Percent removal of total $\mathrm{Cr}$ on polystyrene tris(2-aminoethyl) amine as a function of contact time by ICP-MS spectrometry $\left(T=25^{\circ} \mathrm{C}\right.$, $\mathrm{pH}=5$, Adsorbent dosage $=10 \mathrm{~g} / \mathrm{L}$, Initial concentration of $\mathrm{Cr}(\mathrm{VI})=10$ $\mathrm{ppm})$.

percent removal as measured by $\mathrm{Cr}$ (VI) and by total $\mathrm{Cr}$ increased with increasing contact time and attained equilibrium at 120 minutes. These results revealed that 120 minutes was the optimum contact time needed to attain equilibrium. Therefore, in all subsequent measurements, the adsorption contact time was set at 120 minutes.

Figure 5 displays the effect of contact time on the emergence of $\mathrm{Cr}$ (III) in solution. It is evident that the concentration of $\mathrm{Cr}$ (III) in solution passes through an induction period, an adsorption period and a saturation period. It took 20 min for $\mathrm{Cr}$ (III) to build up in solution. Once accumulated, it is removed by adsorption on the polymer until it reached saturation. This explains the observed fluctuation in its concentration as function of time.

\subsection{Effect of pH}

The percent removal of $\mathrm{Cr}(\mathrm{VI})$ was studied at different $\mathrm{pH}$ values ranging between 2.0 - 6.0 (Figure 6). Whereas the percent removal of $\mathrm{Cr}$ (VI) stayed almost constant as the $\mathrm{pH}$ was increased, that of the total $\mathrm{Cr}$ was found to vary significantly with $\mathrm{pH}$ (Figure 7). This led to the conclusion that the difference was due to the emergence of $\mathrm{Cr}$ (III) ions in the solution. Apparently some of the bound Cr (VI) ions were reduced by the adsorbent to $\mathrm{Cr}$ (III) ions. The concentration of the latter was determined as the difference between the total chromium obtained by ICP-MS and Cr (VI) obtained by UV-Vis spectroscopy. Inspection of Figure 7 reveals that at 


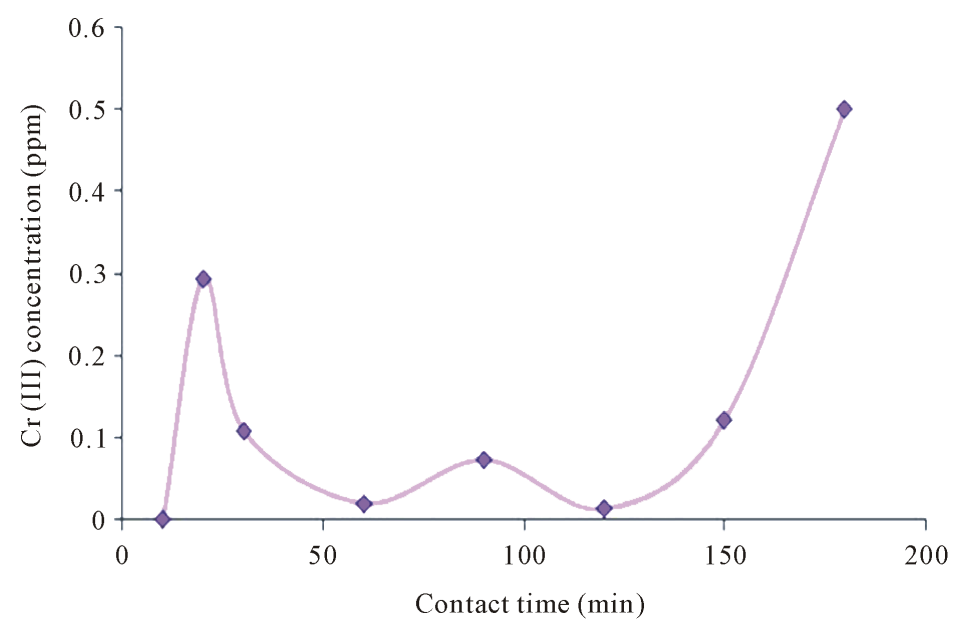

Figure 5. Concentration of $\mathrm{Cr}$ (III) found in solution as a function of contact time with polystyrene tris(2-aminoethyl)amine by ICP-MS spectrometry $\left(T=25^{\circ} \mathrm{C}, \mathrm{pH}=5\right.$, Adsorbent dosage $=10 \mathrm{~g} / \mathrm{L}$, Initial concentration of $\mathrm{Cr}(\mathrm{VI})=10 \mathrm{ppm})$.

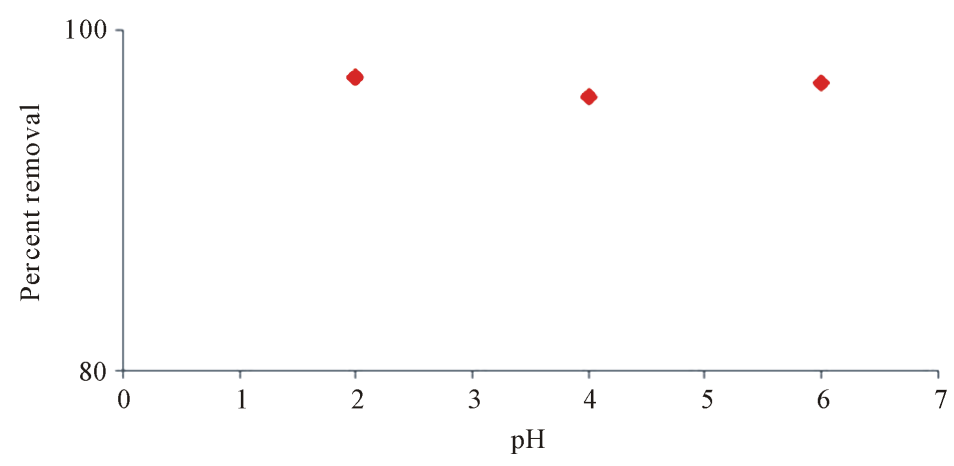

Figure 6. Percent removal of $\mathrm{Cr}$ (VI) on polystyrene tris(2-aminoethyl) amine as a function of $\mathrm{pH}$ by UV-Visible spectroscopy $\left(T=25^{\circ} \mathrm{C}\right.$, Adsorbent dosage $=10 \mathrm{~g} / \mathrm{L}$, Contact time $=2$ hours, Initial concentration $=$ $10 \mathrm{ppm})$.

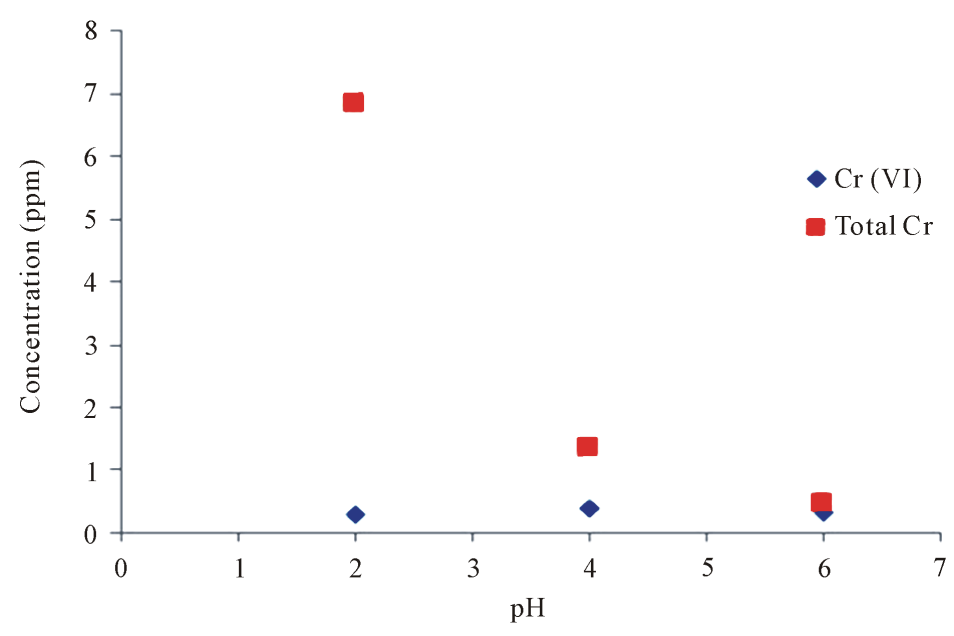

Figure 7. Concentration of Chromium remaining in solution as a function of $\mathrm{pH}\left(T=25^{\circ} \mathrm{C}\right.$, Contact time $=2$ hours, Adsorbent dosage $=10 \mathrm{~g} / \mathrm{L}$, Initial concentration $=10 \mathrm{ppm}$ ). 
$\mathrm{pH}=2$ the concentration of $\mathrm{Cr}$ (III) available in solution was about $7 \mathrm{ppm}$, then it dropped significantly when the $\mathrm{pH}$ was raised. It is known that the reduction of $\mathrm{Cr}$ (VI) to $\mathrm{Cr}$ (III) is also catalyzed by $\mathrm{H}^{+}$[10] [11]. Hence the rate of reduction is much higher at $\mathrm{pH}=2$ than that at $\mathrm{pH}$ 6, leading to the observed increase in [Cr (III)] at $\mathrm{pH}=2$.

In agreement with previously reported results [10] [11], two mechanisms appear to be involved in the removal of $\mathrm{Cr}$ (VI) by polystyrene tris-2-(aminoethyl) amine; adsorption and reduction. So the removal can be performed by any of the two processes. If the intention is to remove $\mathrm{Cr}(\mathrm{VI})$, then $\mathrm{pH}=6$ should be chosen. While if the intention is to detoxify $\mathrm{Cr}(\mathrm{VI})$, then the redox process is the preferred route and this should be performed at $\mathrm{pH}$ $=2$.

\subsection{Effect of Initial Cr (VI) Concentration}

The effect of initial Cr (VI) concentration on the percent removal of Chromium was studied over the range 10.0 to $80.0 \mathrm{mg} / \mathrm{L}$ at the optimum contact time of 120 minutes, $\mathrm{pH}=5.0$ and at an adsorbent dosage of $10 \mathrm{~g} / \mathrm{L}$ (Figure 8). The results obtained by UV-Visible and by ICP-MS, indicated that the percent removal of $\mathrm{Cr}$ (VI) decreased with increasing initial concentration.

\subsection{SEM and EDS Analyses}

The scanning electron microscope images (Figure 9) showed an increase in average particle size from $71 \mu \mathrm{m}$ (polystyrene tris(2-aminoethyl)amine alone) to $88 \mu \mathrm{m}$ (polystyrene tris(2-aminoethyl)amine bound to $\mathrm{Cr}(\mathrm{VI})$ ), this increase in average particle size is caused by the complexation of $\mathrm{Cr}(\mathrm{VI})$ to the polymer.

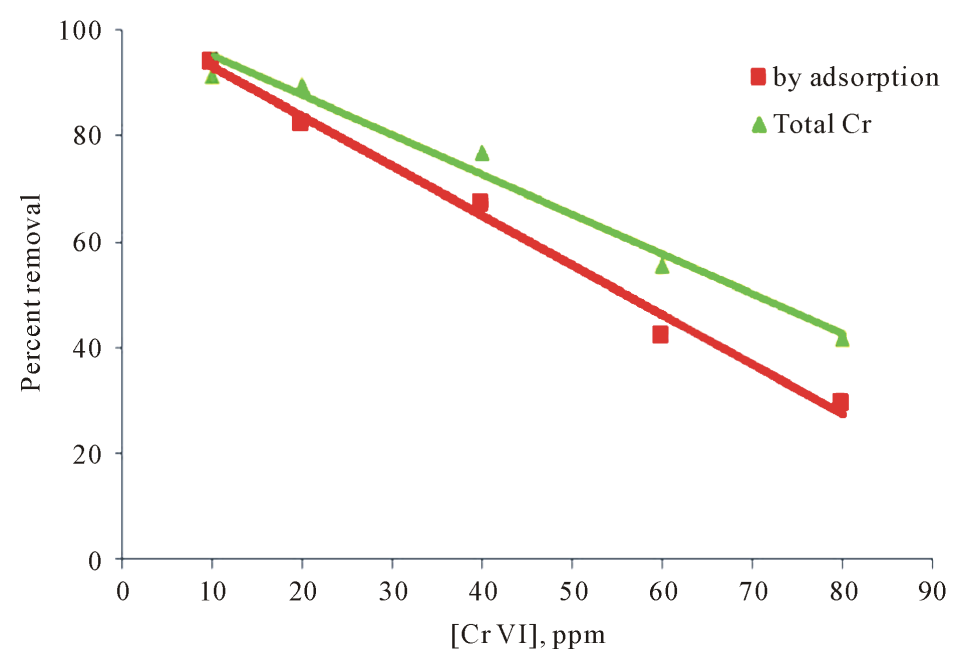

Figure 8. Percent removal of $\mathrm{Cr}(\mathrm{VI})$ and total $\mathrm{Cr}$ on polystyrene tris(2-aminoethyl)amine as a function of initial concentration of $\mathrm{Cr}$ (VI) $\left(T=25^{\circ} \mathrm{C}, \mathrm{pH}=5\right.$, Contact time $=2$ hours, Adsorbent dosage $\left.=10 \mathrm{~g} / \mathrm{L}\right)$.

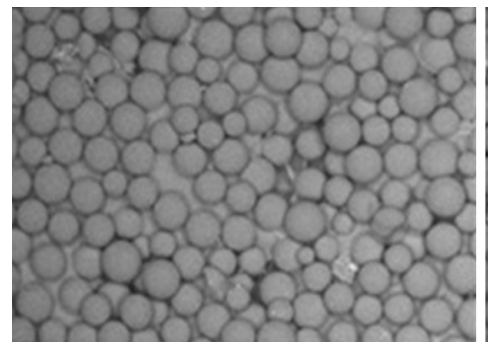

(a)

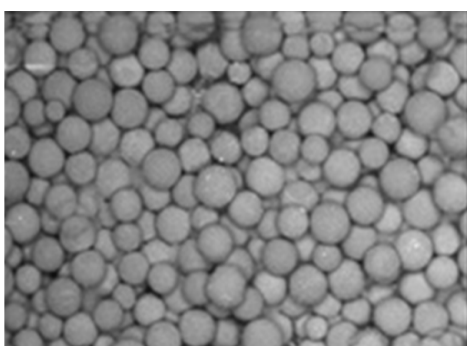

(b)

Figure 9. SEM images for microspheres of (a) polystyrene tris(2-aminoethyl) amine (b) polystyrene tris(2-aminoethyl)amine bound to $\mathrm{Cr}$ (VI). 
Elemental analysis using Energy Dispersive Spectrometry showed the appearance of $\mathrm{Cr}$ after the complexation of polystyrene tris(2-aminoethyl)amine with $\mathrm{Cr}$ (VI) ions. The appearance of S is attributed to the use of sulfuric acid in $\mathrm{pH}$ adjustment (Table 1 and Table 2).

\subsection{Regeneration of the Adsorbent}

The concentration of $\mathrm{Cr}$ (VI) desorbed was $0.27 \mathrm{ppm}$ while the total chromium found in the solution was 4.13 $\mathrm{ppm}$. The difference (3.85 ppm) represented the concentration of $\mathrm{Cr}$ (III) exchanged by $\mathrm{KCl}$ solution. Hence, we can conclude that the adsorbent reduced almost all the bound $\mathrm{Cr}$ (VI) to $\mathrm{Cr}$ (III). The percent desorption was calculated using the initial concentration of $\mathrm{Cr}$ (VI) on the adsorbent and the final concentration of $\mathrm{Cr}$ (III) and $\mathrm{Cr}(\mathrm{VI})$ in $\mathrm{KCl}$ solution and was found to be $89.3 \%$.

\subsection{Testing the Removal of $\mathrm{Cr}$ (VI) by the Regenerated Adsorbent}

The percent removal of $\mathrm{Cr}$ (VI) by the regenerated adsorbent was $95.11 \%$. The removal capacity of the latter adsorbent was comparable to that of the original polymer which was $96.74 \%$. This demonstrates the high efficiency of $\mathrm{KCl}$ in desorbing chromium from polystyrene tris(2-aminoethyl)amine.

\subsection{Adsorption Isotherms}

To model the adsorption behavior, two adsorption isotherms were studied and their correlation with the experimental data was assessed.

\subsubsection{Langmuir Isotherm}

Langmuir equation may be written as

$$
C_{e} / q_{e}=1 / Q_{\max } K+C_{e} / Q_{\max }
$$

where $q_{e}$ is the amount of solute adsorbed per unit weight of adsorbent $(\mathrm{mg} / \mathrm{g}), C_{e}$ is the equilibrium concentration of solute in the bulk solution $(\mathrm{mg} / \mathrm{L}), Q_{\max }$ is the adsorption capacity $(\mathrm{mg} / \mathrm{g}), K$ is the constant related to the free adsorption energy.

A plot of $C_{e} / q_{e}$ versus $C_{e}$ was linear and the constants $Q_{\max }$ and $K$ were determined from the slope and intercept of the plot respectively. The correlation coefficient obtained with the Langmuir equation was high by UV-Vis $\left(R^{2}=0.9997\right)$ and ICP-MS $\left(R^{2}=0.9891\right)$ indicating a good fit between the parameters (Figure 10 and Figure 11). $Q_{\max }=312.27 \mathrm{mg} / \mathrm{g}$ and $K=0.947$ at $T=25^{\circ} \mathrm{C}$ and $\mathrm{pH}=5$ with $10 \mathrm{~g} / \mathrm{L}$ adsorbent dosage. Compared with other adsorbents (Table 3), polystyrene tris(2-aminoethyl)amine showed high adsorption capacity.

\begin{tabular}{ccc}
\hline \multicolumn{3}{c}{ Table 1. Elemental analysis of polystyrene tris(2-aminoethyl)amine. } \\
\hline Element Line & Weight \% & Atom \% \\
\hline Al K & 46.09 & 52.90 \\
Cl K & 53.91 & 47.10 \\
Total & 100.00 & 100.00 \\
\hline
\end{tabular}

Table 2. Elemental analysis of polystyrene tris(2-aminoethyl)amine bound to $\mathrm{Cr}(\mathrm{VI})$.

\begin{tabular}{ccc}
\hline Element Line & Weight \% & Atom \% \\
\hline Al K & 19.91 & 26.35 \\
S K & 37.36 & 41.61 \\
Cl K & 8.39 & 8.45 \\
Cr K & 34.35 & 23.59 \\
Total & 100.00 & 100.00 \\
\hline
\end{tabular}


Table 3. Adsorption capacity of various adsorbents.

\begin{tabular}{|c|c|c|}
\hline Adsorbent & $\begin{array}{c}\text { Adsorption } \\
\text { capacity (mg/g) }\end{array}$ & Reference \\
\hline Sawdust & 4.4 & [17] \\
\hline Coconut fibers & 29 & [12] \\
\hline Palm fibers & 14 & [12] \\
\hline Barks & 12 & [13] \\
\hline Coniferous leaves & 5 & [14] \\
\hline Carbonized tea leaves & 43 & [15] \\
\hline Quaternized cellulose derivatives & 7 & [1] \\
\hline Cationized cellulose & 64.5 & [18] \\
\hline Cationized wood sawdust & 39.5 & [18] \\
\hline Cationized maize-cob flour & 41.6 & [18] \\
\hline Activated charcoal & 45.24 & [19] \\
\hline Cooked tea dust & 30.39 & [20] \\
\hline Neem sawdust & 58.82 & [21] \\
\hline Mango sawdust & 37.73 & [22] \\
\hline Wheat hunk & 28.08 & [22] \\
\hline Sugarcane bagasse & 23.8 & [22] \\
\hline Orange peel & 19.8 & [22] \\
\hline Polystyrene tris-2-(aminoethyl)amine & 312.27 & This work \\
\hline
\end{tabular}

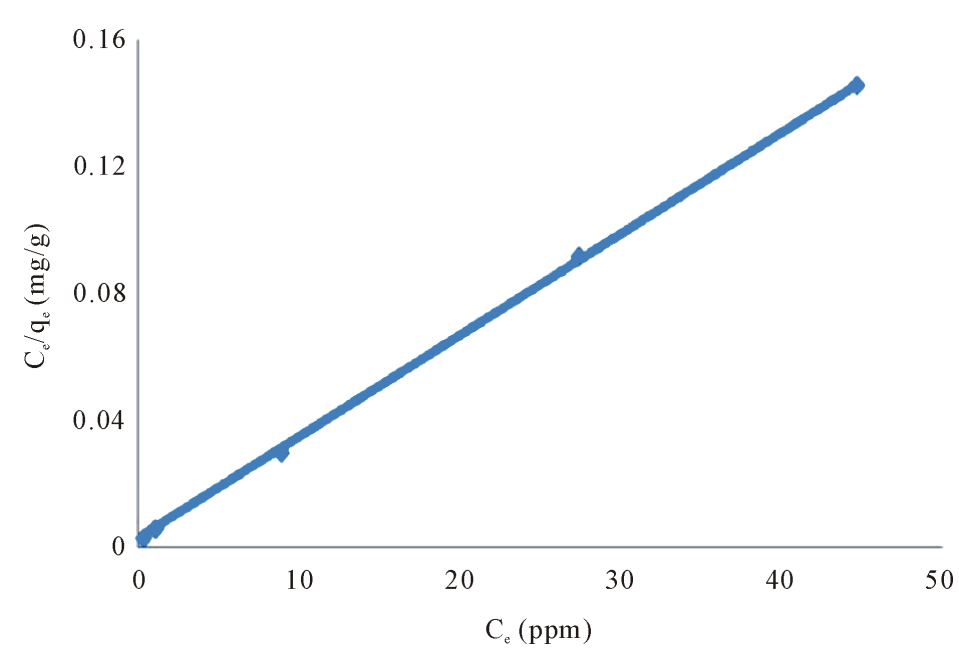

Figure 10. Langmiur isotherm for the adsorption of $\mathrm{Cr}(\mathrm{VI})$ using UVVis spectroscopy $\left(T=25^{\circ} \mathrm{C}, \mathrm{pH}=5\right.$, Contact time $=2$ hours, Adsorbent dosage $=10 \mathrm{~g} / \mathrm{L})$. 


\subsubsection{Freundlich Isotherm}

The Freundlich isotherm is expressed by the following equation

$$
\log X / m=\log K_{f}+1 / n \log C_{e}
$$

where $X / \mathrm{m}$ is the amount of solute adsorbed per unit weight of adsorbent $(\mathrm{mg} / \mathrm{g}), C_{e}$ is the equilibrium concentration of solute in the bulk solution $(\mathrm{mg} / \mathrm{L}), K_{f}$ is a constant indicative of the relative adsorption capacity of the adsorbent (mg/g), $1 / n$ indicates the intesity of the adsorption.

A plot of $\log X / m$ versus $\log C_{e}$ was non linear, indicating bad fit between parameters (Figure 12). The regression coefficient $\left(R^{2}\right)$ were 0.9997 for Langmuir isotherm and 0.8837 for Freundlich isotherm. The $R^{2}$ values indicated that Langmuir isotherm model is the best to describe the removal of $\mathrm{Cr}$ (VI) ions by polystyrene tris(2-aminoethyl)amine. The Freundlich isotherm model does not agree well with the adsorption process. So monolayer coverage occurred on the available active sites on the adsorbent.

\subsection{Proposed Mechanism of Adsorption}

Apparently, the adsorption mechanism initially starts with an electrostatic attraction between the ammonium ions, generated at acidic $\mathrm{pH}$ from the amino groups attached to the polymer, with the predominant chromium

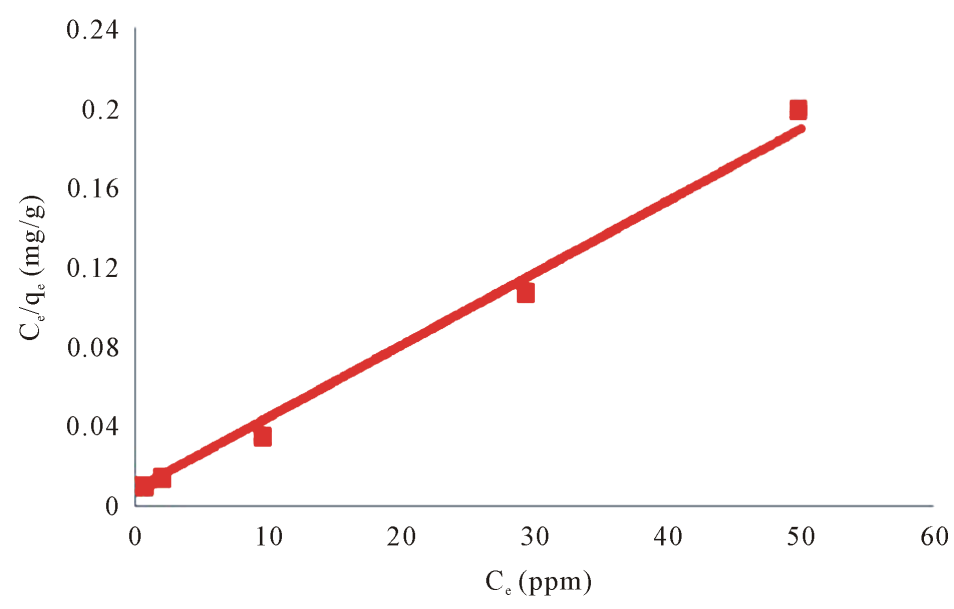

Figure 11. Langmiur isotherm for the adsorption of $\mathrm{Cr}$ (VI) using ICPMS spectroscopy $\left(T=25^{\circ} \mathrm{C}, \mathrm{pH}=5\right.$, Contact time $=2$ hours, Adsorbent dosage $=10 \mathrm{~g} / \mathrm{L})$.

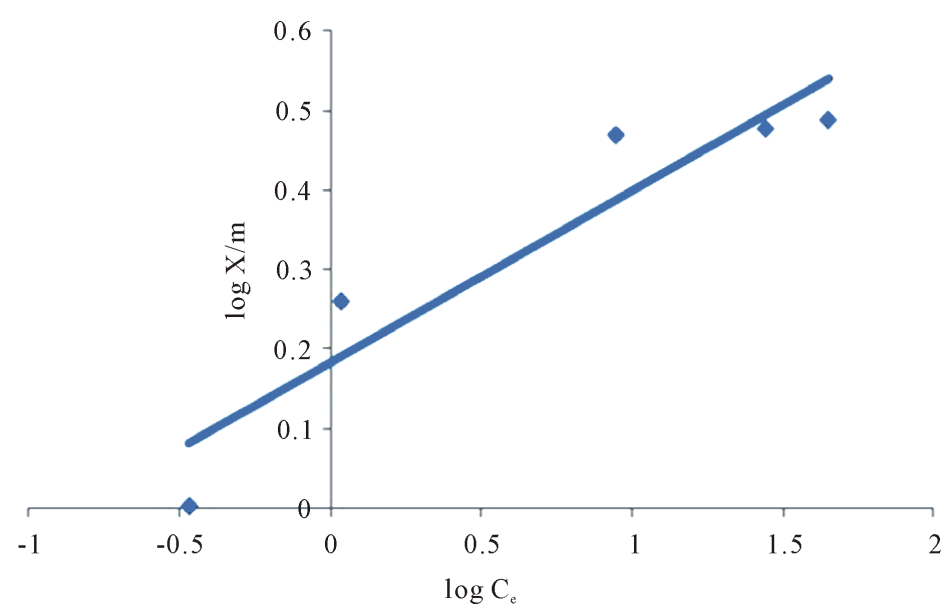

Figure 12. Freundlich isotherm for the adsorption of Cr (VI) using UVVis spectroscopy $\left(T=25^{\circ} \mathrm{C}, \mathrm{pH}=5\right.$, Contact time $=2$ hours, Adsorbent dosage $=10 \mathrm{~g} / \mathrm{L})$. 
species, $\mathrm{HCrO}_{4}^{-}$[16]. This is followed by reduction to $\mathrm{Cr}$ (III) and complex formation with the four amino groups situated on the polymer [23] [24]. The adsorbent itself being oxidized to the $\mathrm{N}$-oxide as apparent from the IR spectrum that shows a small band at about $940 \mathrm{~cm}^{-1}$ corresponding to the $\mathrm{N}-\mathrm{O}$ stretching vibration. Also the bands in the region $1100-800 \mathrm{~cm}^{-1}$ corresponding to C-N stretching vibrations have shifted to lower frequencies indicating complexation of the polymer with chromium (Figure 13). The generated $\mathrm{Cr}$ (III) was either released to the aqueous phase or adsorbed depending on the availability of free sites. Upon addition of $1 \mathrm{M} \mathrm{KCl}$ to the adsorbent, $\mathrm{Cr}$ (III) was released to the solution and was determined by ICPMS (Figure 14).

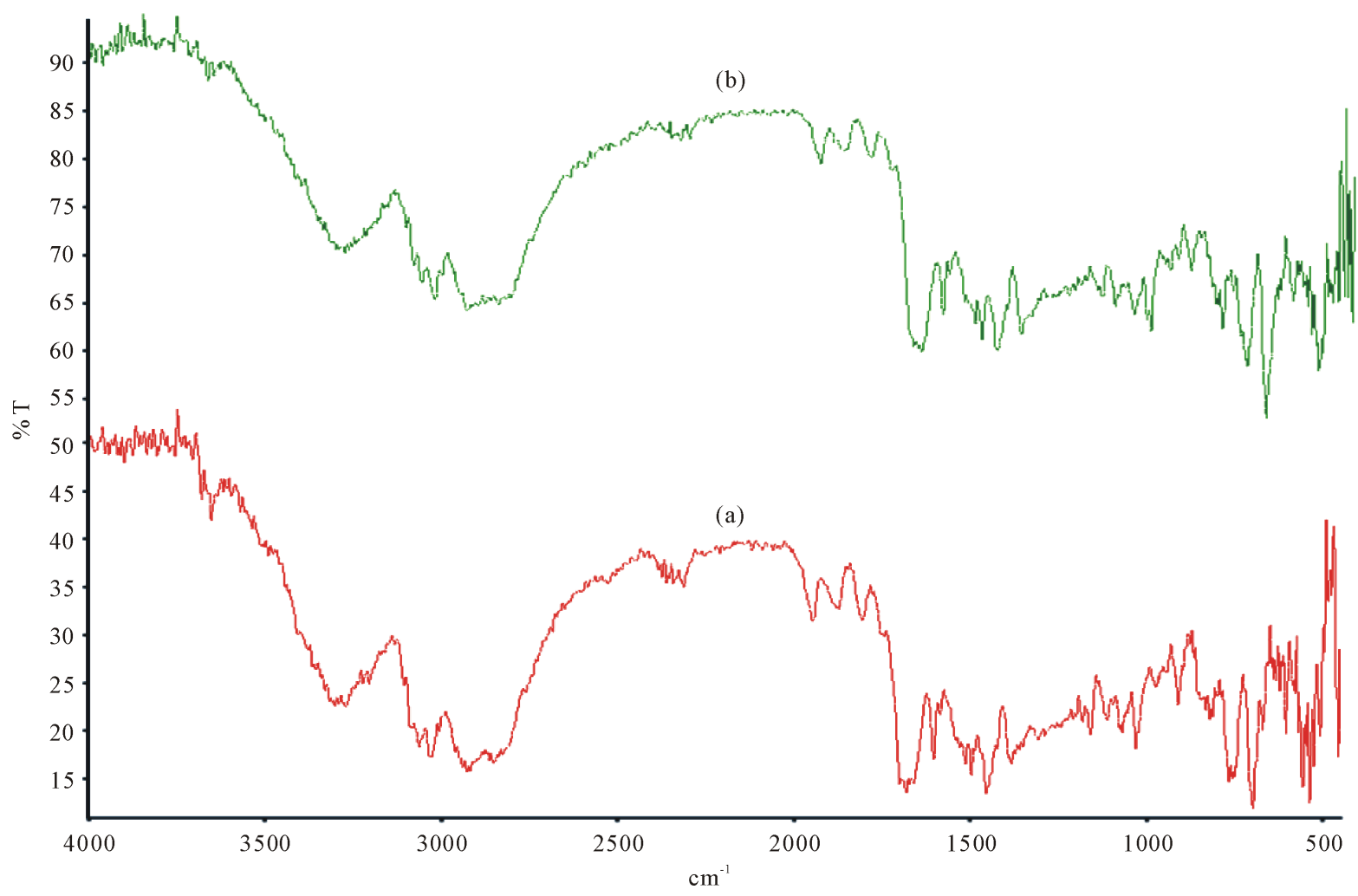

Figure 13. FTIR of (a) polystyrene tris(2-aminoethyl)amine and (b) polystyrene tris(2-aminoethyl)amine-Cr complex.

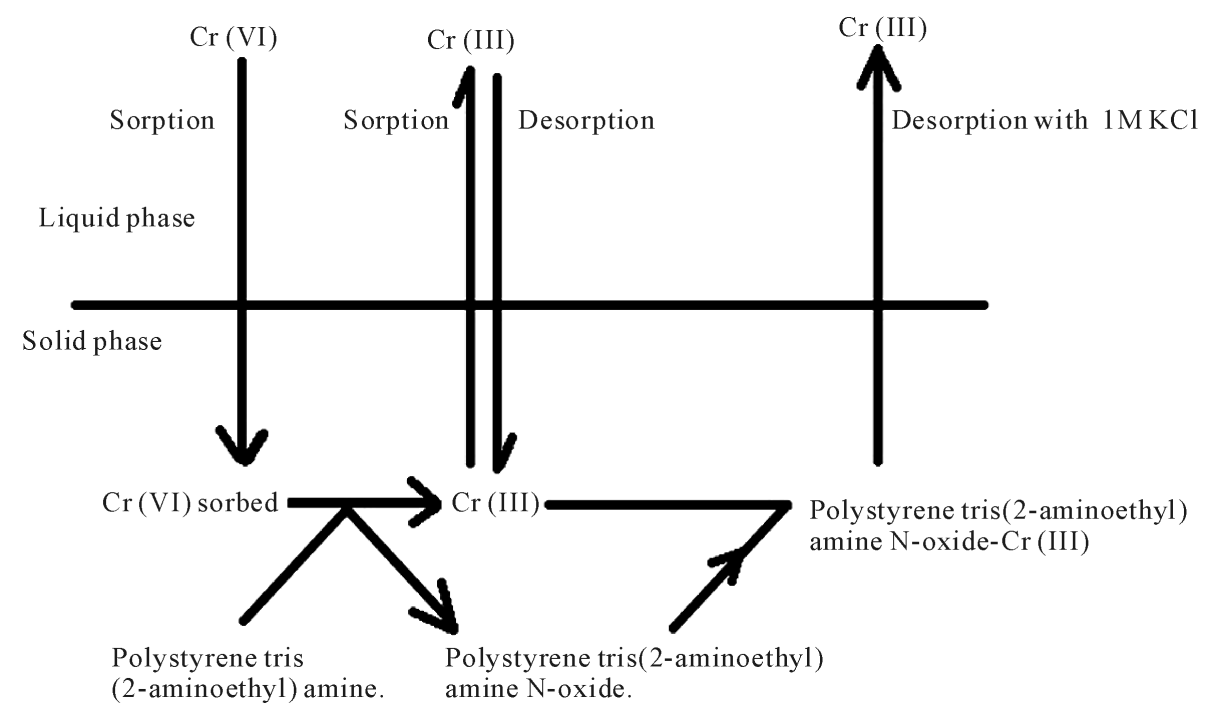

Figure 14. Proposed mechanism of adsorption of $\mathrm{Cr}$ (VI) by polystyrene tris(2-aminoethyl)amine. 


\subsection{Adsorption Capacity of Various Adsorbents}

The adsorption capacity of the polystyrene tris(2-aminoethyl)amine under ambient $\mathrm{pH}$ and at $25^{\circ} \mathrm{C}$ was found to be $312.27 \mathrm{mg} / \mathrm{g}$ of adsorbent. This is about five times more than the most efficient adsorbent reported earlier, particularly, Neem sawdust and cationized cellulose (Table 3). The acceptable cost and the efficiency of our adsorbent makes it a good candidate for the removal of $\mathrm{Cr}(\mathrm{VI})$ from aqueous media.

\section{Conclusion}

Polystyrene tris-2-(aminoethyl)amine has been successfully used to remove $\mathrm{Cr}$ (VI) from aqueous solutions. The removal of $\mathrm{Cr}(\mathrm{VI})$ was best at $\mathrm{pH}$ 6, and the percentage of $\mathrm{Cr}(\mathrm{VI})$ removed depended on adsorbent dosage, contact time and initial Cr (VI) concentration. During the adsorption process detoxification of Cr (VI) occured by its reduction to $\mathrm{Cr}$ (III). The Langmuir isotherm model agreed well with the experimental data and the maximum adsorption capacity was $312.27 \mathrm{mg} / \mathrm{g}$.

\section{Acknowledgements}

We wish to thank Professor Dr. Z. Abdeen for his valuable financial support which made this work possible. We also wish to thank the Aquatic and Aquaculture Research Laboratory at Al-Quds University for performing the ICP-MS analysis.

\section{References}

[1] Nakano, Y., Takeshita, K. and Tsutsumi, T. (2001) Adsorption Mechanism of Hexavalent Chromium by Redox within Condensed-Tannin Gel. Water Research, 35, 496-500. http://dx.doi.org/10.1016/S0043-1354(00)00279-7

[2] Escudero, C., Fiol, N., Poch, J. and Villaescusa, I. (2009) Modeling of Kinetics of Cr (VI) Sorption onto Grape Stalks Waste in a Stirred Batch Reactor. Journal of Hazardous Materials, 170, 286-291. http://dx.doi.org/10.1016/j.jhazmat.2009.04.100

[3] Demirbas, E., Kobyab, M., Senturkb, E. and Ozkana, T. (2004) Adsorption Kinetics for the Removal of Chromium (VI) from Aqueous Solutions on the Activated Carbons Prepared from Agricultural Wastes. Water SA, 30, 533-540. http://dx.doi.org/10.4314/wsa.v30i4.5106

[4] Anderson, R.A., Polansky, M.M., Bryden, N.A., Patterson, K.Y., Veillon, C. and Glinsmann, W.H. (1983) Effects of Chromium Supplementation on Urinary Cr Excretion of Human Subjects and Correlation of Cr Excretion with Selected Clinical Parameters. The Journal of Nutrition, 113, 276-281.

[5] Baranowska-Dutkiewicz, B. (1981) Absorption of Hexavalent Chromium by Skin in Man. Archives of Toxicology, 47, 47-50.

[6] Gibb, H.J. and Lees, P.S. (2000) Lung Cancer among Workers in Chromium Chemical Production. American Journal of Industrial Medicine, 38, 115-126. http://dx.doi.org/10.1002/1097-0274(200008)38:2<115::AID-AJIM1>3.0.CO;2-Y

[7] Kumar, P.A., Ray, M. and Chakraborty, S. (2007) Hexavalent Chromium Removal from Wastewater Using Aniline Formaldehyde Condensate Coated Silica Gel. Journal of Hazardous Materials, 143, 24-32. http://dx.doi.org/10.1016/j.jhazmat.2006.08.067

[8] Mahvi, A.H., Dariush, N., Forughand, V. and Nazmara, S. (2005) Tea Waste as an Adsorbent for Heavy Metal Removal from Industrial Wastewaters. American Journal of Applied Sciences, 2, 372-375. http://dx.doi.org/10.3844/ajassp.2005.372.375

[9] Howard, A.G. and Arbab-Zavar, M.H. (1979) The Preconcentration of Mercury and Methylmercury on DithizoneCoated Polystyrene Beads. Talanta, 26, 895-897. http://dx.doi.org/10.1016/0039-9140(79)80274-X

[10] Fiol, N., Escudero, C. and Villaescusa, I. (2008) Chromium Sorption and Cr (VI) Reduction to Cr (III) by Grape Stalks and Yohimbe Bark. American Journal of Applied Sciences, 99, 5030-5036. http://dx.doi.org/10.1016/j.biortech.2007.09.007

[11] Daneshvar, N., Salari, D. and Aber, S. (2002) Chromium Adsorption and Cr (VI) Reduction to Trivalent Chromium in Aqueous Solutions by Soya Cake. Journal of Hazardous Materials, 94, 49-61. http://dx.doi.org/10.1016/S0304-3894(02)00054-7

[12] Tan, W.T., Ooi, S.T. and Lee, C.K. (1993) Removal of Chromium (VI) from Solution by Coconut Husks and Palm Pressed Fibers. Environmental Technology, 14, 277-282. http://dx.doi.org/10.1080/09593339309385290

[13] Singh, D.K., Saksena, D.N. and Tiwari, D.P. (1994) Removal of Chromium (VI) from Aqueous Solutions. Indian Journal of Environmental Health, 36, 272-277. 
[14] Cho, N.S., Aoyama, M., Seki, K., Hayashi, N. and Doi, S. (1999) Adsorption by Coniferous Leaves of Chromium Ions from Effluent. Journal of Wood Science, 45, 266-270. http://dx.doi.org/10.1007/BF01177738

[15] Singh, D.K. and Lal, J. (1992) Removal of Cr (VI) from Aqueous Solutions Using Waste Tea Leaves Carbon. International Journal of Electronic Healthcare, 34, 108-113.

[16] Zaki, M.I., Fouad, N.E., Leyrer, J. and Knozinger, H. (1986) Physicochemical Investigation of Calcinedchromia-Coated Silica and Alumina Catalysts: Characterization of Chromium-Oxygen Species. Applied Catalysis, 21, 359-377. http://dx.doi.org/10.1016/S0166-9834(00)81368-8

[17] Zarraa, M.A. (1995) Study on the Removal of Chromium (VI) from Wastes Solutions by Adsorption onto Sawdust in Vessels. Adsorption Science and Technology, 12, 129-138.

[18] Zghida, H., Hassen, M., Baouab, V. and Gauthier, R. (2003) Sorption of Chromium Oxy-Anions onto Cationized LingoCellulosic Materials. Journal of Applied Polymer Science, 87, 1660-1665. http://dx.doi.org/10.1002/app.11596

[19] Alfa-Sika, M., Liu, F. and Chen, H. (2010) Optimization of Key Parameters for Chromium (VI) Removal from Aqueous Solutions Using Activated Charcoal. Journal of Soil Science and Environmental Management, 1, 55-62.

[20] Dhanakumar, S., Solaraj, G., Mohanraj, R. and Pattabhi, S. (2007) Removal of Cr (VI) from Aqueous Solution by Adsorption Using Cooked Tea Dust. Indian Journal of Science and Technology, 1, 1-6.

[21] Vinodhini, V. and Das, N. (2009) Mechanism of Cr (VI) Biosorption by Neem Sawdust. American-Eurasian Journal of Scientific Research, 4, 324-329.

[22] Vinodhini, V. and Das, N. (2009) Biowaste Materials as Sorbents to Remove Chromium (VI) from Aqueous Environment. ARPN Journal of Agricultural \& Biological Science, 4, 19-23.

[23] Gandhi, M.R., Viswanathan, N. and Meenakshi, S. (2010) Adsorption Mechanism of Hexavalent Chromium Removal Using Amberlite IRA 743 Resin. Ion Exchange Letters, 3, 25-35.

[24] Nastasovic, A., Sandic, Z., Surucic, L., Maksind, D., Jakovljevic, D. and Onjiad, A. (2009) Kinetics of Hexavalent Chromium Sorption on Amino-Functionalized macroporous Glycidyl Methacrylate Copolymer. Journal of Hazardous Materials, 171, 153-159. http://dx.doi.org/10.1016/j.jhazmat.2009.05.116 
Scientific Research Publishing (SCIRP) is one of the largest Open Access journal publishers. It is currently publishing more than 200 open access, online, peer-reviewed journals covering a wide range of academic disciplines. SCIRP serves the worldwide academic communities and contributes to the progress and application of science with its publication.

Other selected journals from SCIRP are listed as below. Submit your manuscript to us via either submit@scirp.org or Online Submission Portal.
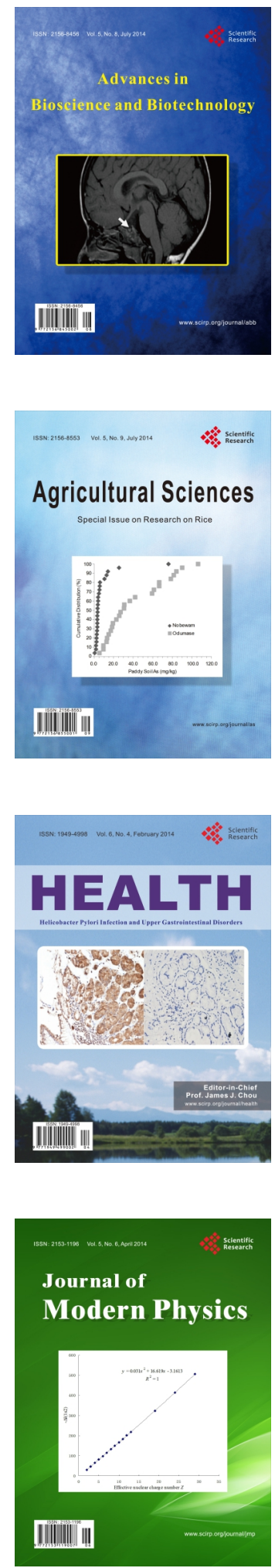
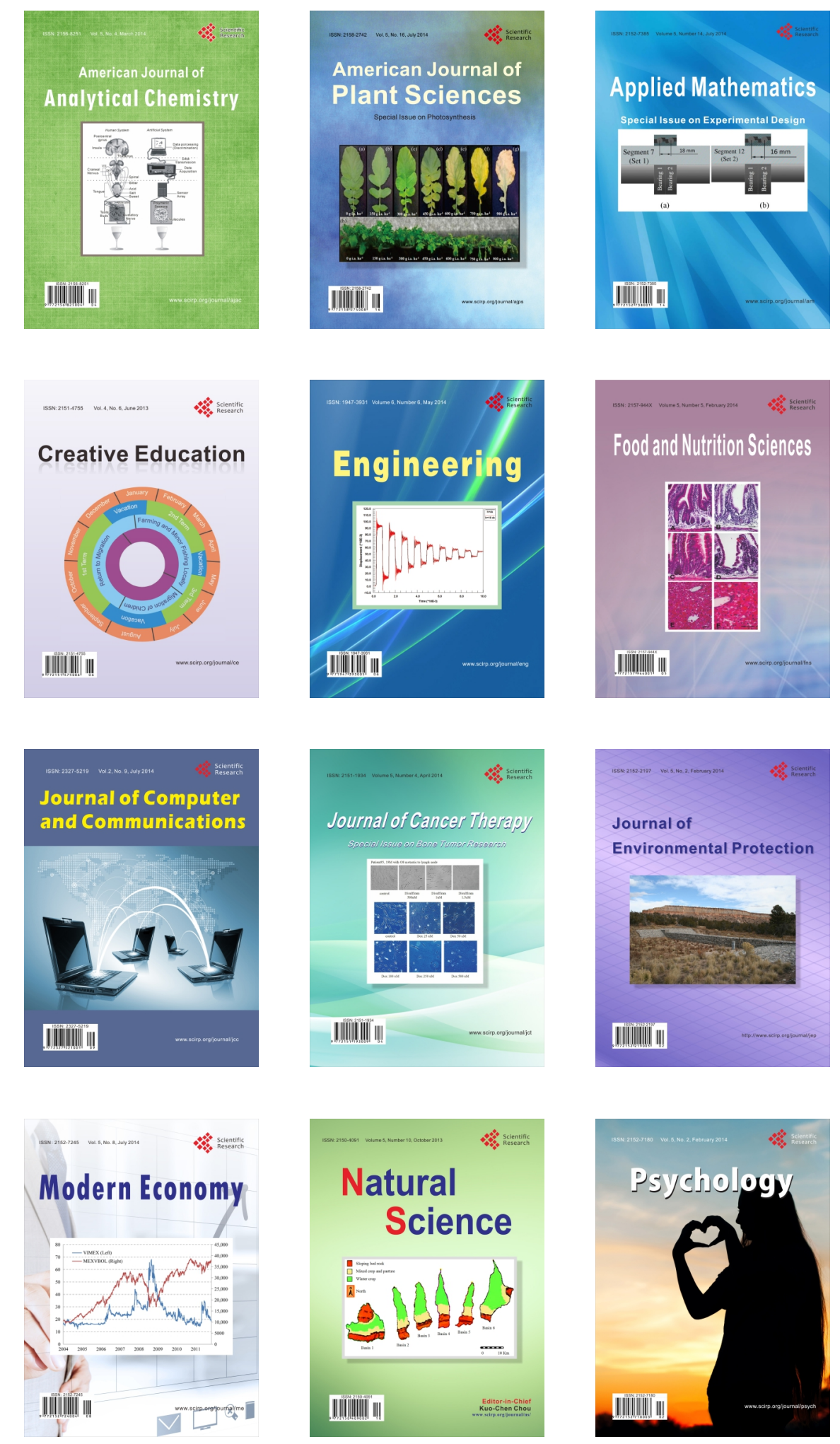